\title{
Economic Efficiency Soybean Production: The Case of Smallholder Farmers in Pawe Woreda, Ethiopia: Parametric Approach
}

\author{
Birhanu Argaw \\ School of Agricultural Economics and Agribusiness, Haramaya University \\ Jema Haji \\ School of Agricultural Economics and Agribusiness, Haramaya University \\ PO box 138, Dire Dawa, Ethiopia \\ Mohammed Aman \\ School of Agricultural Economics and Agribusiness, Haramaya University \\ PO box 138, Dire Dawa, Ethiopia
}

\begin{abstract}
This study was initiated with the objective of assessing economic efficiency of soybean production. A multistage sampling technique was employed to select 203 soybean farm households randomly from Pawe Woreda, Metekel zone, Benishangul-Gumuz Regional State, Ethiopia. Parametric stochastic production frontier approach was used to estimate technical, allocative and economic efficiency levels, whereas Tobit model was used to identify factors affecting economic efficiency. The mean technical, allocative and economic efficiencies were $72.72 \%, 35.378 \%$ and $25.05 \%$, respectively, indicating there was significant amount of economic inefficiency in production. The Tobit model result showed that important factors that affected technical, allocative and economic efficiency are age, level of education, extension service, access for credit, farming experience, off/nonfarm income participation and training. Based on the findings the following recommendations are forwarded. Government should devote a great effort on a reduction in the interest rate, bureaucracies and collaterals of banks on loans which will facilitate credit accessibility to smallholder farmers, strengthening and establishing both formal and informal type of framers education and strengthen the existing agricultural extension system.
\end{abstract}

Keywords: Pawe woreda, soybean, efficiency, Cobb-Douglas, Tobit

DOI: $10.7176 / \mathrm{JESD} / 12-15-01$

Publication date:August $31^{\text {st }} 2021$

\section{Introduction}

The economic growth of Africa, more than any other continents, depends on the improvement of the agricultural and agro-industry sectors, which are mainly affected by the productivity of resources so that the inappropriate use of resources in these nations matter significantly. This is in particular true for Sub-Saharan Africa where agriculture is the fundamental contributor to the majority of their gross domestic product (GDP) and it is the major source of earnings and employment (Henao and Baanante, 2006). As a result, one of the foremost policy concerns of the governments in these countries nowadays is to reap sustainable development that fulfill economic objective (Girmay, 2006).

Similar to most of African countries, agriculture plays a central role to achieve economic growth in Ethiopia. The sector contribute $36.3 \%$ of the country Gross Domestic Product (GDP) and it additionally function a source of employment opportunities to more than $73 \%$ of total population that is involved in agriculture, generates about $70 \%$ of the foreign exchange earning of the country and $70 \%$ raw materials for the industry in the country (UNDP, 2018). This shows that the overall economy of the country and the food security of the majority of the population rely on agriculture. However, the sector is explained by low performance, caused by a combination of natural calamities, demographic factors, socio-economic factors, backward and poor technologies and lack of knowledge on the efficient utilization of limited resources particularly on land and capital (WFP, 2012). Hence, being an agriculture dependent country with a food deficit gap, increasing crop production and productivity is not a matter of choice rather a must to attain food self-sufficiency.

Soybean is gaining ground globally because of its multipurpose use as human food, livestock feed, industrial purposes, and more recently, as a supply of bio energy (Myaka et al., 2005).Producing and consuming more soybean would enhance the circumstance (Food Security) as soy gives a nutritious mix of each calorie and protein consumption. Moreover, this crop is the most nutritionally wealthy crop, it contains $40 \%$ of protein compared to $18 \%$ from meat and $11 \%$ from eggs (Chianu et al., 2008).

According to CSA (2018) annual report, grain crops constitute the majority of the annual total agricultural crop production. During this period, the total crop cultivated area and production of grain crops were 15,270,526 
ha and 342,174,543 qt, respectively. The same source indicated that in Ethiopia, the total cultivated area and production of pulses crops were 2,053,557 ha and 33,534,836 qt respectively (CSA, 2018). Among pulses, soybean covered $38,072.70$ ha of land at country wide level and 864,678.69 qt of soybean have been produced with the average productivity of 22.71 quintal per hectare. Similarly, in Benishangul -Gumuz region, the total area covered by soybean during the main cropping season of 2017/18 were 14, 076.52 ha and 300,939.73 qt of soybean have been produced with the productivity of 21.38 quintal per hectare.

Currently, the government of Ethiopia has given due consideration for soybean production as industrial crop and its production is anticipated to expand from 0.72 million quintals in 2015 to 1.2 million quintals by the year 2020 to meet the demand of the market by means of making a linkage with the enterprise industry and worldwide market (GTP II 2015, cited in GebreeEgziabher, 2020). Albeit this plan is designed to maximize soybean production, little emphasizes for measuring and identifying determinants of smallholder farmers efficiency may reduce the potential for success. Thus, assessing efficiency of the local farmers may lead to better achievements.

In Pawe woreda, soybean is the major pulses crop produced in the area followed by haricot bean. This crop is mainly serving as major source of income and protein to farmers. However, productivity of this vital crop in Pawe woreda is low (below 20 quintal per ha) (Birhanu et al., 2018). It is therefore important to evaluate whether the yields are low because smallholder farmers inefficient in their input use. As a result there is a need to quantitatively measure the production efficiency levels and their determinants for smallholder soybean producers in the study area.

In Ethiopia, the volume of soybean production during the last seventeen years has been increased (CSA, 2001-2017). Despite the increased volume of soybean production, its national average yield (22.71quintal per ha) remains low as compared to the world average yield (27.6 quintal per ha) (CSA, 2018). Besides, spatial variability in soybean productivity is another concern for soybean productivity enhancement in Ethiopia. For instance, in 2018/19, the average soybean productivity in Ethiopia varied from 23.20 quintals per ha (Oromiya region) to 21.38 quintals per hectare (Benishangul-Gumuz region). Similarly, the average soybean productivity varied in other regions too (CSA, 2018). Therefore, increasing production levels and reducing its variability are both essential aspects to improved food security and well - being of the people of Ethiopia.

Moreover, the growing demand for soybean at local and international markets has a clear message that we have to produce more soybean by increasing cultivated or increasing its productivity. However, extensive cultivation of land will affect natural ecosystems and may result in a heavy cost such as huge and irreversible losses of biodiversity (WWF, 2014). Given that majority of farmers in Ethiopia are smallholders and operate on limited area, how can the growing demand for soybean will be meet? Is it possible to increase soybean production and productivity without contributing to deforestation and habitat loss? These are important questions that needs to be addressed. Therefore, countries particularly Ethiopia must consider ways to meet soybean demand in the context of this growing demand. This situation requires research on the levels as well as the determinants of efficiency of soybean production in the country. These are the prerequisites of any policy formulation for a sustainable production of soybean in Ethiopia.

Albeit there are various empirical study conducted related to soybean production(for example (Fitsum, 2016; Birhanu et al., 2018; Welay and Desalegn, 2019) in Pawe but efficency aspect was not studied yet. Consequently, further research on measuring economic efficiencies of soybean production under smallholder farmers in Pawe woreda is required. Therefore, this study is carried out to fill this gap of knowledge.

\section{Methodology}

\subsection{Study area}

This study was conducted in Pawe woreda, Metekel zone, Benshangul-Gumuz region, North Western Ethiopia. The area is located about $570 \mathrm{~km}$ away from Addis Ababa between $36^{\circ} 20^{\prime} 36^{\circ} 32^{\prime}$ - longitude and $11^{\circ} 12^{\prime}-11^{\circ}$ 21 'north latitude. The study area is one of the seven districts of Metekel Zone of Benshangul-Gumuz Regional State. The woreda has total of 20 kebeles and the climate of the area is hot humid and characterized by unimodal rainfall pattern with high and torrential rainfall that exceeds from May to October. The area receives mean annual rainfall of $1586.32 \mathrm{~mm}$ and mean annual temperature of $160 \mathrm{c}$ to $320 \mathrm{c}$ which ranges $120 \mathrm{c}$ to $400 \mathrm{c}$ (Fitsum, 2016). The farming system of the woreda is characterized as mixed crop-livestock farming system dominated by cereal and pulses crops. Among the pulses, soybean takes a lion share in terms of production and area coverage (CSA, 2018). The woreda is bounded in East and North by Jawi district, in South by Mandura district, in West by Dangur districts. Despite the fact that the area is potential for crop production, agricultural productivity is generally low and it is subsistence oriented. Livestock and its product contribute a significant proportion of cash income for households.

\subsection{Sampling techniques and the data}

In this study, combinations of multi-stage purposive and random sampling techniques were employed to draw an 
appropriate sample households. In the first stage, out of seven woredas in Metekel zone, Pawe woreda is selected purposively for its long year experience in soybean production. In the second stage, out of the total of 20 soybean producer kebeles in the woreda, three kebeles were selected by using simple random sampling method. Consequently, the three selected kebeles are kebele 26, kebele 24, and kebele 23/45. The total sample size for this study was computed to be 203 .

\subsection{Analytical methods}

The analysis of efficiency was carried out following the Aigner et al. (1977) method of the estimating the Stochastic Frontier Production Functions (SFPF). The study specified the SFPF using a Cobb-Douglas and Translog production function for smallholder soybean producing farmers in the Pawe woreda, Metekel zone, Benishangul -Gumuz Regional state Ethiopia. The linear form of Cobb-Douglas production function is represented in Equation 1.

$\ln Y_{i}=\beta_{0}+\ln \sum \beta_{j} X_{i j}+\varepsilon_{i}$

$\varepsilon_{i}=v_{i}+u_{i}$

Here ln denotes the natural logarithm; $\mathrm{j}$ represents the number of inputs used; $i$ represents the $i^{\text {th }}$ farmer in the sample; Y represents the observed soybean production of the $i^{\text {th }}$ farmer; $\mathrm{X}_{\mathrm{ij}}$ denotes $\mathrm{j}^{\text {th }}$ farmer input variables used in soybean production of the $i^{\text {th }}$ farmer; $\beta$ stands for the vector of unknown parameters to be estimated; $\varepsilon_{\mathrm{i}}$ is a composed disturbance term made up of two elements $\left(v_{i}\right.$ and $\left.u_{i}\right) ; v_{\mathrm{i}}$ accounts for the stochastic effects beyond the farmer's control, measurement errors as well as other statistical noises and $u_{\mathrm{i}}$ captures the technical inefficiency.

The Trans log stochastic frontier production function initially developed by Aigner et al. (1977) and Meeusen and Van den Broeck (1977) specified as:

$\ln Y_{i}=\sum_{k=1}^{7} \beta_{k} \ln X_{i k}+\frac{1}{2} \sum_{k=0}^{7} \sum_{j=0}^{7} \beta_{j k} \ln X_{i j} \ln X_{i j}+v_{i}-u_{i}$

Where $\ln$ denotes the natural logarithm, $Y_{i}$ represents output of the $i^{\text {th }}$ producer, k represents the number of inputs used, $X_{i j}$ represents a set of 7 input variables (land, labor, seed, oxen power, chemicals, dap, and urea) used by the $i^{\text {th }}$ farmer, and $\beta$ is a vector that collects unknown parameters to be estimated. The random error $v_{i}$ accounts for the stochastic effects beyond the farmers control, measurement errors as well as other statistical noise, and $u_{i}$ captures production inefficiency due to factors that are in the control of the farmer. Both of the Cobb-Douglas and Trans log production function have their own advantage and limitation. However, in this study, the appropriate functional form which best fit the data was selected by using likelihood ratio test.

The solution to the cost minimization problem is the basis for deriving the dual cost frontier, given the input price $\left(\omega_{j}\right)$, parameter estimates of the stochastic frontier production function $(\hat{\beta})$ and adjusted output level $Y_{k}^{i *}$.

$\operatorname{MinC}=\sum_{n} \omega_{n} x_{n}$

Subject to $\quad 1 \mathrm{RE}$

$Y_{k}^{i *}=\hat{\mathrm{A}} \prod_{n} x_{n} \hat{\beta}_{n}$

Where $\hat{\mathrm{A}}=\exp \left(\hat{\beta}_{0}\right), \omega_{n}=$ input price, $\hat{\beta}=$ parameter estimates of the stochastic production function and $Y \stackrel{i}{i *}=$ input oriented adjusted output level from equation 3 .

The following dual cost function will be found by substituting the cost minimizing input quantities into Equation 4.

$C\left(Y_{k}^{i *}, w\right)=H Y_{k}^{i * \mu} \prod_{n} \omega_{n} \alpha_{n}$

Where $\alpha_{n}=\mu \hat{\beta}_{n}, \mu=\left(\sum_{n} \hat{\beta}_{n}\right)-^{1}$ and $H=\frac{1}{\mu}\left(\hat{\mathrm{A}} \prod_{n} \hat{\beta}_{n} \hat{\beta}_{n}\right)-{ }^{\mu}$

Therefore, the efficiency indices of the given farmer can be calculated as follows:

$\mathrm{TE}=\frac{\mathrm{Y}}{\mathrm{Y} *}$

Where $\mathrm{Y}^{*}$ represents frontier output, Y represents actual yield

$E E=\frac{C}{C *}$

Where, $C^{*}$ represents minimum (efficient) cost, $\mathrm{C}$ represents actual cost.

Following Farrell (1957), allocative efficiency index of the ith farmer can be derived from Equations 5 and 6 as follows;

$A E=\frac{E E}{T E}$ 
In this study after measuring the level of efficiency, a Tobit model employed to identify the hypothesized socioeconomic and institutional factors that affect performance of farmers. This model is best suited for such analysis because of the nature of the dependent variable (efficiency scores), which takes values between 0 and 1 and yield the consistent estimates for unknown parameter vector (Maddala, 1999).

Following Maddala (1999) the Tobit model can be specified as:

$Y_{i}^{*}=\beta_{0}+\sum \beta_{\text {Xim }}+\mu_{i}$

Where $Y_{i}^{*}$ represents latent variable representing the efficiency scores of farmer $i$; $\beta$ represents a vector of unknown parameters; $X_{i m}$ represents a vector of explanatory variables $m(m=1,2 \ldots k)$ for farm $i$ and $\mu_{i}$ represents an error term that is independently and normally distributed with mean zero and variance $\sigma^{2}$.

Denoting $y_{i}$ as the observed variables, $y_{i}=y\left\{\begin{array}{rr}1 & \text { if } y_{i}^{*} \geq 1 \\ 0 & y_{i}^{*} \text { if } 0<y_{i}^{*}<1 \\ & \text { if } y_{i}^{*} \leq 0\end{array}\right.$

Table1. Definition of efficiency variables and expected signs

\begin{tabular}{llll}
\hline Description of variables & Types & Unit measurement & Expected sign \\
\hline $\begin{array}{l}\text { Dependent variables: } \\
\text { allocative and economic efficiency }\end{array}$ & Technical, Continuous & Percent & \\
$\begin{array}{l}\text { Independent variables: } \\
\text { Age }\end{array}$ & Continuous & Years & - \\
Sex of the household head & Dummy & 1, for male, 0 otherwise & + \\
Education level of household head & Continuous & Number & + \\
Family size & Continuous & Number & $+/-$ \\
Farm size & Continuous & Hectare & $+/-$ \\
Frequency of extension contact & Continuous & Number & + \\
Access to credit & Dummy & 1, for access, 0 otherwise & + \\
Home to farm distance & Continuous & Number & - \\
Distance to the nearest market & Continuous & Number & - \\
Training & Dummy & 1, got training, 0 otherwise & + \\
Livestock size & Continuous & Number & + \\
Off-farm income participation & Dummy & 1, engaged off, 0 otherwise & + \\
Farming experience & Continuous & Year & + \\
Perception of soil fertility & Dummy & 1, fertile, 0 otherwise & + \\
Perception of slope of land & Dummy & 1, flat, 0 otherwise & + \\
Membership to cooperative & Dummy & 1, Member, 0 otherwise & $+/-$ \\
\hline
\end{tabular}

\section{Results and Discussion}

\subsection{Estimation of production and cost functions}

The dependent variable in the production function was soybean production (Qt/ha) and the input variables used in the analysis were area under soybean (ha), labor (man days in man equivalent), quantity of seed (kg), quantity of DAP $(\mathrm{kg})$, quantity of urea $(\mathrm{kg})$, oxen (pair of oxen days) and chemical (litter). In total seven input variables were estimated in both of ordinary least squares and maximum likelihood estimation for comparison. Out of the seven input variables estimated in the maximum likelihood estimate, land, labor and DAP were statistically significant at $1 \%, 5 \%$ and $5 \%$ levels, respectively (Table 2 ). 
Table 2. OLS and ML estimate for the Cobb- Douglas production function

\begin{tabular}{lllll}
\hline Variables & OLS & MLE & Std.Err \\
\hline Land & Coefficient & Std.Err & Coefficient & 0.05799 \\
Labor & $0.5513^{* *}$ & 0.0615 & $0.5478^{* * *}$ & 0.06178 \\
Seed & $0.1280^{*}$ & 0.0684 & $0.1445^{* *}$ & 0.11210 \\
DAP & $0.2954^{*}$ & 0.1164 & 0.1805 & 0.00504 \\
Urea & 0.0088 & 0.0053 & $0.0106^{* *}$ & 0.004366 \\
Oxen power & 0.0004 & 0.0047 & 0.0001 & 0.06442 \\
Chemical & 0.1020 & 0.0693 & 0.0552 & 0.04015 \\
Constant & 0.0156 & 0.0423 & 0.0091 & 0.52076 \\
Lambda & $0.8757^{*}$ & 0.5288 & $1.7694 * * *$ & 0.08302 \\
Sigma square & & & 1.6797 & 0.04429 \\
Gama & & & 0.2725 & 0.7383 \\
Retura
\end{tabular}

Return to scale $=0.948$

Note: The symbol ***,** and * shows the level of significance at 1,5 and $10 \%$, respectively.

The parametric coefficients of significant input variables were $0.5478,0.1445$, and 0.0106 for area, labor and DAP, respectively (Table 2). These values indicate the relative importance of each factor in soybean production. Therefore, a $1 \%$ increase in the use of land, labor and DAP will result in $0.5478 \%, 0.1445 \%$, and $0.0106 \%$ increase in the level of soybean output, respectively. Consequently, land (area) appeared as one of the major important factor of production followed by labor and DAP in the order, respectively. This indicates that other things remaining constant, a $1 \%$ increase in area will increase the output of soybean output by $0.5478 \%$. The return to scale value that is obtained from the maximum likelihood estimation of the Cobb-Douglas production function was 0.948 which indicates a $1 \%$ increase in all the specified production inputs will increase output by $0.948 \%$. Therefore, an increase in all production inputs by one percent will increase soybean yield by less than one percent. It can be escaped from stage III of production area by using their existing resources and technology efficiently in the production process. This result was consistent with a study by Gbigbi (2011) in Nigeria found returns to scale to be 0.85 . The estimated value of gamma is 0.7384 which indicates that $73.84 \%$ of the variation in soybean output was due to technical inefficiency, while the remaining $26.36 \%$ variation was due to the effect of random noise. This implies that there was a scope for improving soybean production by identifying the institutional, socioeconomic and farm specific factors causing this variation.

Inadequate farm level price data coupled with little or no input price variation across farmers of Ethiopia precludes any econometric estimation of a cost or profit frontier function. Therefore, the use of self-dual production function allows the cost frontier function to be derived and used to estimate economic efficiency in situations where producers face the same prices was given as follows:

$$
\begin{aligned}
& \ln C m_{i}=2.433+0.033 \omega_{1 i}+0.3737 \omega_{2 i}+0.0066 \omega_{3 i}+0.0055 \omega_{4 i}+0.0867 \omega_{5 i}+ \\
& 0.2836 \omega_{6 i}+0.0874 \omega_{7 i}+0.0261 \ln Y_{i}^{*}
\end{aligned}
$$

Where $\mathrm{C}$ is cost of producing soybean; $Y_{i}^{*}$ refers to the index of output adjusted for any statistical noise; $\omega_{1}$ is the observed seasonal rent of a hectare of land; $\omega_{2}$ is the daily wage of labor; $\omega_{3}$ is the price of DAP per kg; $\omega_{4}$ is the price of Urea per $\mathrm{kg}$; $\omega_{5}$ is the price of seed per $\mathrm{kg}$; $\omega_{6}$ is the daily rent of oxen and $\omega_{7}$ is the price index of chemicals per liter.

\subsection{Efficiency scores}

Out of the total 203 sampled households, about $71(34.98 \%)$ respondents in the study area were operating above the technical efficiency level of $80 \%$ while $106(52.22 \%)$ of them were operating in the range of $60-80 \%$ of technical efficiency levels. Moreover, 21 (10.34\%) of the farmers was operating from 40-60\% of technical efficiency level. Only 5 (2.46\%) of sampled households were in the range $20-40 \%$ of technical efficiency level. However, none of sampled households were operating below $20 \%$ of technical efficiency level. Moreover, the result showed that the potential to improve soybean productivity for individual sampled households through improvement in the level of technical is the smallest as compared to that of the allocative efficiency and economic efficiency (Table 3).

The mean technical effic0iency of sample respondents was about $72.72 \%$ with minimum of 30.54 and maximum level of $94.66 \%$. Therefore, if the average smallholder farmer of the sample could achieve the technical efficiency level of its most efficient counterpart, then average sample farmerse could increase their output by $23.17 \%$ approximately [that is, $1-(72.72 / 94.66)$ ] 100 . Similarly the most technically inefficient sample farmer could increase the production by $67.73 \%$ approximately [that is, $1-(30.54 / 94.66)]^{*} 100$ if he could increase the level of technical efficiency to his most efficient counterpart. The average allocative efficiency of 
sampled households was about $35.38 \%$ with minimum $15.44 \%$ and a maximum of $62.50 \%$. This implies that farmers are not allocatively efficient in producing soybean and hence, a farmer with average level of allocative efficiency would enjoy a cost saving of about $43.39 \%(1-0.3538 / 0.6250) * 100$ to attain the level of the most efficient farmer. The most allocative inefficient farmer would have an efficiency gain of $75.29 \%$ derived from $(10.1544 / 0.6250) * 100$ to attain the level of the most efficient farmer. The mean economic efficiency of the sample farmers was also about $0.2505 \%$ with minimum $0.1277 \%$ and maximum of $0.4012 \%$. This indicates that there was a significant level of economic inefficiency in the production process. The producer with an average economic efficiency level could reduce current average cost of production by $62.43 \%$ to achieve the potential minimum cost level without reducing output levels. It can be inferred that if farmers in the study area were to achieve 100\% economic efficiency, they would experience substantial production cost saving of $62.43 \%$. Sampled households in the study area were relatively good in technical efficiency than allocative efficiency or economic efficiency. However, none of the respondents had a technical, allocative and economic efficiency of 100 percent.

Table 3. Summary statistics and frequency distribution efficiency estimates

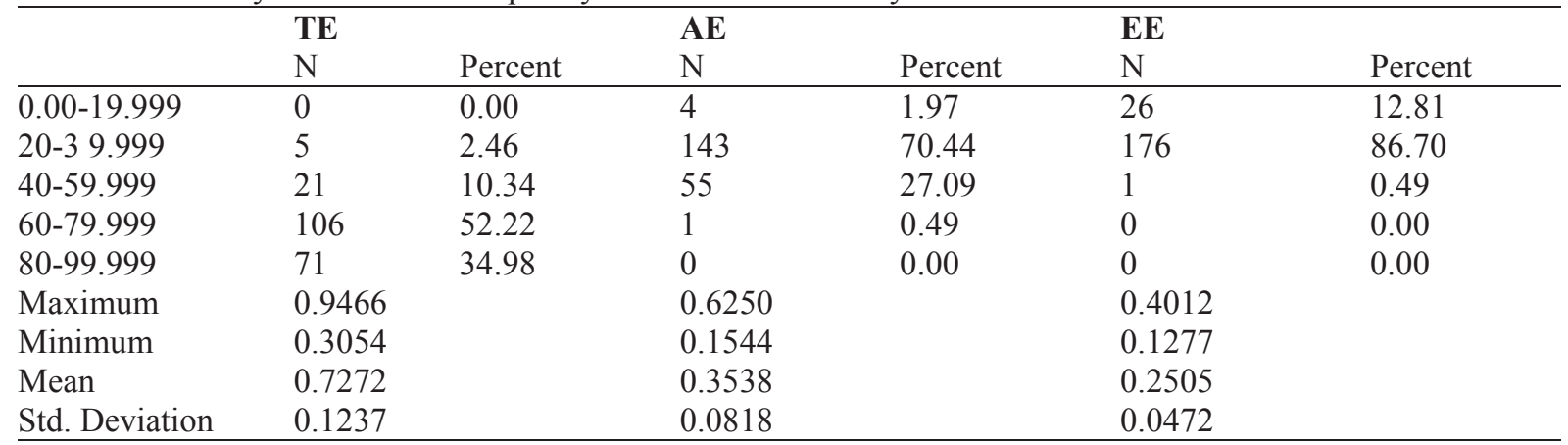

\subsection{Determinants of Efficiency in soybean production}

Technical, allocative and economic efficiency of sample respondents were estimated and regressed on socioeconomic and institutional variables that explain variations in efficiency across sampled households using two-limit Tobit regression model.

Age of the household head had a negative and significant effect on allocative and economic efficiencies of soybean production in the study district at 5\% significance levels each. This implies that older farmers were allocatively and economically less efficient than younger ones. This was probably as the farmer gets older, his ability to manage farming activities becomes decreased. The computed marginal effect of age of the sampled households showed that other thing remain constant, a one year increase in the age of the sampled household head would decrease the probability of the sampled farmers being allocatively and economically efficient by 0.02 and $0.02 \%$ and the expected value of allocative efficiency and economic efficiency by 0.18 and $0.1 \%$ with an overall decrease in the probability and the level of efficiency by 0.19 and $0.11 \%$, respectively. This result is in line with the findings of some studies (Battese and Coelli, 1992; Battese and Coelli, 1995; Kye and Oppen, 1999).

Access to credit has a positive and significant effect on technical efficiency of soybean production. This variable is significant at 5\% significance level. The positive sign shows that credit recipient are more technically efficient than their counterpart of non-recipient. This might be due to the fact that credit permits a sample smallholder farmer to enhance efficiency by overcoming liquidity constraints. Hence, use of credit access ensures timely acquisition and use of agricultural inputs such as improved seed, DAP, Urea, herbicide, education and implement farm management decisions on time and these results increased production of efficiency. This suggests that availability of credit is an important factor for attaining a higher level of technical efficiency. Thus, use of credit access increases the probability of farmers to fall under technically efficient by $0.05 \%$ and the expected value of technical efficiency by $3.51 \%$ with an overall increase in the probability and the level of technical efficiency by $0.92 \%$. This result is in line with study done by Kifle (2014) and Sandip and Mohamed (2018).

Farming experience of soybean producers significantly and positively affected allocative and economic efficiencies at 5 and $1 \%$ significance levels, respectively. This might be experience is a proxy for managerial aspects and improves the skill and technical capacity that helps to best match inputs and in cost saving aspect so attain higher productivity at minimum cost. The marginal effect result indicates that keeping all other variables constant, an increase in farm experience of sampled respondent by one year would increase the probability of respondents to fall under allocative and economic efficient by $0.02 \%$ and $0.03 \%$ and the expected value of allocative and economic efficiency by 0.22 and $0.17 \%$ with an overall increase in the probability and the level of efficiencies by 0.23 and $0.18 \%$, respectively. The result is consistent with previous findings (Mustefa et al., 2017; 
Leake et al., 2018; Regasa et al., 2019).

As expected, frequency of extension contact had positive sign and statistically significant effect on allocative and economic efficiency at 5\% and $1 \%$ significance levels, respectively, but it was statistically insignificant for technical efficiency. This implies that households who getting more frequent extension contact increased the allocative and economic efficiency. The marginal effect indicates that keeping all other variables constant, for a one day additional extension agent contact with farmers increases the probability of sampled households to fall under allocatively and economically efficient by $0.03 \%$ and $0.04 \%$ and the expected value of allocative and economic efficiency by about 0.31 and $0.20 \%$ with an overall increase in the probability and the level of efficiencies by 0.3 and $0.19 \%$, respectively. The result is in line with the previous findings done by (Desale, 2017; Mustefa et al., 2017; Osman et al., 2018; Sandip and Muhammed, 2018; Regasa et al. (2019)).

As expected, off/non-farm activity had a positive and significant effect on farmers' technical and economic efficiency at $10 \%$ and $5 \%$ significance levels, respectively. This implies that households participated in off-farm income were more efficient than their counter parts. Participation in off/non-farm income activity affect technical and economic efficiency positively for the reason that the income obtained from such activities could be used for the purchase of agricultural inputs. The marginal effect indicates that holding all other variables remain constant, being households participated in off/non-farm income generating activities would increase the probabilities of households to fall under technically and economic efficient by 0.88 and $0.03 \%$ and change the expected value of technical and economic efficiency by 3.32 and $1.4 \%$ with an overall increase in the probability and level of efficiencies by 3.52 and $1.41 \%$, respectively. The result of this study is found to be similar with some researchers who tried to examine the effect of off/non-farm income participation on economic efficiency (Getahun, 2014; Kifle, 2014; Milkessa et al., 2019).

The result indicated that training was positively and significantly affect technical and economic efficiencies at $1 \%$ and $5 \%$ significance levels, respectively. This implies that sampled households who have received any kind of training related to soybean production was relatively good in technical and economic efficiency than who did not received training. This is due to the fact that training increases the awareness of farmers and exposes to new ideas and information about productivity of inputs, opportunities, input and output management, marketing and prudent handling of cash. The marginal effect indicates that holding all other variables remain constant, as farmers got training, the probabilities of sample households would increase to fall under technically and economically efficient by 3.2 and $0.03 \%$ and the expected value of technical and economic efficiency by 6.89 and $2.36 \%$ with an overall increase in the probability and level of efficiencies by $7.5 \%$ and $2.4 \%$, respectively. Similar results were found in the work of Getahun (2014) and Moges (2018) 
Table 4. Marginal effects of efficiency factors

\begin{tabular}{|c|c|c|c|c|c|c|}
\hline \multirow{2}{*}{ Variables } & \multicolumn{2}{|l|}{ TE } & \multicolumn{2}{|l|}{$\mathrm{AE}$} & \multicolumn{2}{|l|}{ EE } \\
\hline & $\begin{array}{l}\text { Coefficient } \\
\text { (Robust.std.err) }\end{array}$ & $\begin{array}{l}\text { Marginal } \\
\text { effects }\end{array}$ & $\begin{array}{l}\text { Coefficient } \\
\text { (Robust.std.err) }\end{array}$ & $\begin{array}{l}\text { Marginal } \\
\text { effects }\end{array}$ & $\begin{array}{l}\text { Coefficient } \\
\text { (Robust.std.err) }\end{array}$ & $\begin{array}{l}\text { Marginal } \\
\text { effects }\end{array}$ \\
\hline AGEHH & $\begin{array}{l}0.00061 \\
(0.0011)\end{array}$ & $\begin{array}{l}0.0006 \\
0.0005 \\
0.0001\end{array}$ & $\begin{array}{l}-0.00183 * * \\
(0.00095)\end{array}$ & $\begin{array}{l}-0.0019 \\
-0.0018 \\
-0.0002\end{array}$ & $\begin{array}{l}-0.00105^{* *} \\
(0.00044)\end{array}$ & $\begin{array}{l}-0.0011 \\
-0.0010 \\
-0.0002\end{array}$ \\
\hline ACSTCDT & $\begin{array}{l}0.0377 * * \\
(0.0176)\end{array}$ & $\begin{array}{l}0.0372 \\
0.0351 \\
0.0092\end{array}$ & $\begin{array}{l}-0.00963 \\
(0.01256)\end{array}$ & $\begin{array}{l}0.0096 \\
0.0096 \\
0.0001\end{array}$ & $\begin{array}{l}0.00559 \\
(0.00664)\end{array}$ & $\begin{array}{l}0.0055 \\
0.0055 \\
0.0001\end{array}$ \\
\hline EDUCATION & $\begin{array}{c}0.00264 \\
(0.00462)\end{array}$ & $\begin{array}{l}0.0026 \\
0.0024 \\
0.0005\end{array}$ & $\begin{array}{l}0.00723 * * \\
(0.00286)\end{array}$ & $\begin{array}{l}0.0072 \\
0.0071 \\
0.0008\end{array}$ & $\begin{array}{l}0.00369 * * \\
(0.00155)\end{array}$ & $\begin{array}{l}0.0035 \\
0.0036 \\
0.0007\end{array}$ \\
\hline FRMEXP & $\begin{array}{l}-0.00020 \\
0.00136\end{array}$ & $\begin{array}{l}0.0002 \\
0.0001 \\
0.0004\end{array}$ & $\begin{array}{l}0.00239 * * \\
(0.00120)\end{array}$ & $\begin{array}{l}0.0023 \\
0.0022 \\
0.0002\end{array}$ & $\begin{array}{l}0.00182 * * * \\
(0.00051)\end{array}$ & $\begin{array}{l}0.0018 \\
0.0017 \\
0.0003\end{array}$ \\
\hline FQECT & $\begin{array}{l}-0.00034 \\
(0.00199)\end{array}$ & $\begin{array}{l}0.0003 \\
0.0003 \\
0.0007\end{array}$ & $\begin{array}{l}0.00318 * * \\
(0.00147)\end{array}$ & $\begin{array}{l}0.0030 \\
0.0031 \\
0.0003\end{array}$ & $\begin{array}{l}0.00208 * * * \\
(0.00068)\end{array}$ & $\begin{array}{l}0.0019 \\
0.0020 \\
0.0004\end{array}$ \\
\hline OFFARM & $\begin{array}{l}0.03563 * \\
(0.01695)\end{array}$ & $\begin{array}{l}0.0352 \\
0.0332 \\
0.0088\end{array}$ & $\begin{array}{l}-0.00714 \\
(0.01220)\end{array}$ & $\begin{array}{l}0.0071 \\
0.0071 \\
0.0009\end{array}$ & $\begin{array}{l}0.01402 * * \\
(0.00663)\end{array}$ & $\begin{array}{l}0.0141 \\
0.0140 \\
0.0003\end{array}$ \\
\hline TRAINING & $\begin{array}{l}0.07648 * * * \\
(0.02263)\end{array}$ & $\begin{array}{l}0.0750 \\
0.0689 \\
0.0302\end{array}$ & $\begin{array}{l}-0.01257 \\
(0.01525)\end{array}$ & $\begin{array}{l}0.0125 \\
0.0125 \\
0.0002\end{array}$ & $\begin{array}{l}0.02368 * * \\
(0.00954)\end{array}$ & $\begin{array}{l}0.0237 \\
0.0236 \\
0.0003\end{array}$ \\
\hline Constant & $\begin{array}{l}0.65562 * * * \\
(0.08086)\end{array}$ & & $\begin{array}{l}0.31969^{* * *} \\
(0.04908)\end{array}$ & & $\begin{array}{l}0.18461 * * * \\
(0.02567)\end{array}$ & \\
\hline
\end{tabular}

Note: ${ }^{* * *},{ }^{* *}$ and ${ }^{*}$ shows the level of significance at 1,5 and $10 \%$, respectively. Marginal effects computed only for efficiency variables and value in cell explain $\frac{\partial E(y)}{\partial x_{j}}$, (Total change), $\frac{\partial E\left(y^{*}\right)}{\partial x_{j}}$, (Expected change), $\frac{\partial \varphi\left[\left(z_{U}-\varphi\left(z_{L}\right)\right]\right.}{\partial x_{j}}$, (Change in probability)

\section{Conclusions and recommendations}

The result of study found that factors of production (land, labor and DAP) had positive and statistical significance effect on soybean production implying better access and use of these inputs could lead to higher soybean production and productivity in the study area. The result also indicated that there is a higher opportunity for soybean producers to increase output at existing levels of inputs and minimize cost without compromising output with the existing technologies available at the hand of farmers. Therefore, an intervention aiming to improve farmers efficiency in the study area should give due attention for resource allocation in line with output maximization as there is big opportunities to increase output without additional investment.

Age of the household heads, measured in years affect allocative and economic efficiency of soybean producer farmers negatively. This is due to older farmers may not easily able to adopt new technology and modern inputs. Hence, policy makers should devote a great effort to give more training to older farmers than the younger farmer regarding to adoption of new technology and modern inputs in the study area.

The result found that access to credit was very important determining factor that has positive and significant effect to TE in the study area. Credit enables smallholder farmers to purchases inputs that they cannot afford from their own resources, which enhance production and productivity of soybean. Therefore, to improve technical efficiency of small holder farmers' policy makers should devote a great effort on a reduction in the interest rate, bureaucracies and collaterals of banks on loans which will facilitate credit accessibility to 
smallholder farmers. In addition, establishment of adequate rural finance institutions and strengthening of the existing micro-finance institutions and agricultural cooperatives to help farmers in terms of financial support through credit are vital to improve soybean production and productivity.

The result of the study also showed that education is positively and significantly related to the probability of households' allocative and economic efficiency. Thus government has to give due attention for training farmers through strengthening and establishing both formal and informal type of framers' education, farmers' training centers, technical and vocational schools as farmer education would increase both allocative and economic efficiencies.

Farmers who have more experience in soybean production were allocatively and economically efficient than others. This might be due to as farmers get more experience they will have more knowledge and skills that are required for prudent resource allocation. Therefore mechanisms should be devised to encourage farmers with little experience to work with the experienced ones or train them. This could be done via the Farmer Training Center (FTC) in which the experienced farmers are trained and let to diffuse their accumulated practices to the youngsters with less experience.

The result showed that frequency of extension contact has positive and significant contribution to allocative and economic efficiency. This is due to extension service is expected to increase the farmer's knowhow on some agronomic practices such as pest and disease control and adoption of improved seed varieties as well as soil and water conservation technologies. This puts the framer in the better position to utilize his/her limited resource to achieve higher results and hence increase their technical efficiencies. Therefore, extension agents have to give due attention to increase in production in addition to their acknowledgeable effort to input allocation and cost minimization. Moreover, extension services should be increase to farmers by the government agents especially District Agriculture Development Unit, and NGO's to assist these farmers to have easy access to extension so as to increase farm technical and allocative efficiencies.

The study also found that, off/non-farm income activity had a positive and significant effect on technical and economic efficiencies, indicating financing timely and enough use of inputs through additional income generated by off/non-farm farm are critical. Therefore, strategies that enhance the ease use of off-farm employment opportunities would help to increase the timely and appropriate use of inputs for better efficiency in soybean production in the study area.

Training affected technical and economic efficiencies positively and significantly. Provision of training for farmers to improve their skills in use of improved seed, resource management, post-harvest handling, and general farm management capabilities will increase their farm productivity. In addition to strengthening the practical training provided to farmers, efforts should be made to train farmers for relatively longer period of time using the already constructed farmers` training centers and agriculture research demonstration centers.

\section{References}

Aigner, D., Lovell, C., and Schmidt, P. 1977. Formulation and Estimation of Stochastic Frontier Production Function Models. Journal of Econometrics, 6: 21-37.

Battese, G. E., and Coelli, T. J. 1992. Frontier Production Functions, Technical Efficiency and Panel Data: With Application to Paddy Farmers in India. Journal of Productivity Analysis, 3(1):153-169.

Battese, G. E., and Coelli, T. J.1995. Model for Technical Inefficiency Effects in a Stochastic Frontier Production Function for Panel Data. Journal of Empirical Economics 20: 325-32.

Birhanu Ayalew, Adam Bekele and Yalew Mazengia.2018. Analysis of Cost and Return of Soybean Production under Small Holder Farmers in Pawe District, North Western Ethiopia. Journal of Natural Sciences Research: 8 (1): 2224-3186.

CSA (Central Statistical Agency of Federal Democratic Republic of Ethiopia).2001-2017. Annual report.

CSA (Central Statistical Agency). 2018.The federal democratic republic of Ethiopia central statistical agency report on area and production of major crop.

Chianu J., Vanlauwe, B.,Mahasi, J., Katungi, E., Akech, C., Mairura, F. and Sanginga, N. 2008. Soybean situation and outlook analysis: The case of Kenya. Tropical Soil Biology and Fertility Institute of International Center for Tropical Agriculture (TSBF-CIAT). African Network for Soil Biology and Fertility, Nairobi, Kenya.

Desale Gebretsadik. 2017. Technical, Allocative and Economic Efficiencies and Sources of Inefficiencies among Large-scale Sesame Producers in Kafta Humera District, Western Zone of Tigray, Ethiopia: Non-parametric approach. International Journal of Scientific and Engineering Research, 8(6):2229-5518.

Farrell, M.J. 1957. The Measurement of Productive Efficiency. Journal of Royal Statistical Society, (120):253281.

Fitsum Miruts. 2016. Analysis of the Factors Affecting Adoption of Soybean Production technology in Pawe District, Metekel Zone of Benshangul-Gumuz Regional State, Ethiopia. World Scientific News, 5(3):122137. 
Getahun Mengistu. 2014. Technical efficiency in onion production: the case of smallholder farmers in dugda woreda, east shewa zone, Ethiopia. A Thesis Submitted to the School of Agricultural Economics and Agribusiness, Haramaya University, May, 2014 Haramaya University.

Gbigbi, M. 2011. Economic efficiency of smallholder sweet potato producers in Delta State, Nigeria: A case study of Ughelli South Local Government Area. Research Journal of Agriculture and Biological Sciences, 7: 163-168.

Gebre-Egzabher Fentahun. 2020. Production and Marketing trends of soybean in Ethiopia. Journal of International Consumer Marketing.

Girmay Tesfay. 2006. Agriculture, Resource Management and Institutions: A socioeconomic Analysis of Households in Tigray, Ethiopia. PhD Thesis, Wageningen University.

Henao, J., and Baanante, C. 2006. Agricultural production and Soil Nutrient Mining in Africa: Implications for Resource Conservation and Policy Development.

Kifle Degefa. 2014. Economic Efficiency of Smallholder Farmers in Maize Production in Bako Tibe District, Oromia National Regional State, Ethiopia. A Thesis Submitted School of Graduate Studies of Haramaya University.

Kopp, R.J., and. Smith, V.K. 1980. Frontier Production Function Estimates for Steam electric Generation. A comparative Analysis. Southern Economic Journal. 47: 1049-1059.

Leake Gebresilassie, Gidey Kidu, Hareg Gebre-egzabher and Zenebe Abraha. 2018. Resources Use Efficiency of Irrigated Tomato Production of Small-scale Farmers. International journal of Vegetable Science, 24(1): 110 .

Maddala, G.S. 1999. Limited Dependent Variable in Econometrics. Cambridge University Press, New York.

Meeusen, W., and van den Broeck, J. 1977. Efficiency Estimation From Cobb-Douglas Production Function with Composed Error. International Economic Review, 18(2):435-444.

Mustefa Bati, Mulugeta Tilahun and Kumar, P.2017. Economic Efficiency in Maize Production in Ilu Ababor zone, Ethiopia. Research Journal of Agriculture and Forestry sciences, 5(12): 1-8.

Moges Dessale. 2017. Measurement of Technical Efficiency and Its Determinants in Wheat Production: The Case of Smallholder Farmers in Wogidi District, South Wollo Zone Ethiopia. M.Sc. Thesis presented to the School of Graduate Studies of Haramaya University.

Myaka, F. A., Kirenga, G., and Malema, B. 2005. Proceeding of the First National Soybean Stakeholders Workshop, 10 - 11 November 2005, Morogoro, Tanzania.

Osman, A., Donkoh, S. A., Ayamga, M. and Ansah, I. G. K. 2018. Economic efficiency of soybean production in the Northern Region of Ghana. Journal of Agricultural Economics and Agribusiness, 1(1): 2637-3521.

Regasa Dibaba, Mesay Yami, and Adam Bekele. 2019. Analysis of Production Efficiency, Productivity Variances and Resource Allocation Among Smallholder Farmers of Soybean Producers: Evidence From Benishangul-Gumuz Region Ethiopia. International Journal of Research Studies in Agricultural Sciences, 5(7): 18-36.

Sandip, M. and Muhammad, Y. 2018. Determinants of Tomato Farmer's Efficiency in Mymensingh district of Bangladesh: Data Envelopment Analysis approach. Journal of Bangladesh Agricultural University, 16(1): 93-97.

UNDP (United Nations development Programme). 2018. Ethiopia's progress to warding eradicating poverty. Paper to be presented to the inter-agency group meeting on the implementation of the third United Nations decade for the eradication of poverty (2018-2027) Addis Ababa, Ethiopia.

Welay Tesfay and Desalegn Teshale. 2019. Impact of Improved Soybean Variety on Enhancing Productivity and Gross Farm Income of Smallholder in the Case of Pawe and Jawi districts, North Western Ethiopia, Journal of Natural Sciences Research, 9(15): 224-3186.

WFP (World Food Programme). 2012. Crop and Food Security Assessment Mission to Ethiopia. Special Report of Food and Agriculture Organization and World Food Programme. 